\title{
BLOOD SUGAR LEVELS WITH NEUTROPHIL-LYMPHOCYTE RATIO AS A MARKER OF DIABETES MELLITUS IN ELDERLY
}

\author{
Theodora E da Silva ${ }^{1)}$, Ika Christine ${ }^{2)}$, Edith M Djaputra ${ }^{3)}$
}

\begin{abstract}
Introduction: Diabetes mellitus is a chronic metabolic disease, characterized by high blood sugar levels due to abnormal insulin secretion by the pancreas, insulin action, or both. Based on the Basic Health Research results in 2018, the elderly group dominates patients with diabetes mellitus. The diagnosis of diabetes mellitus requires an expensive examination that is not available in all laboratories, especially primary care facilities. Some research suggested that the neutrophil-lymphocyte ratio can be an alternative marker for establishing a diagnosis of diabetes mellitus.

Purpose: To determine the correlation between blood sugar levels and lymphocyte ratio as a marker of diabetes mellitus in the elderly.

Method: This study was an observational analytic study with a cross-sectional approach. Data was collected by conducting interviews, physical examinations, and laboratory examinations. Hypothesis testing in this study used the Spearman correlation test.

Results: A total of 53 respondents were included in this study, with a proportion of 32 female subjects $(60.4 \%)$. The mean age of respondents was $76.0 \pm 7.29$ years. An insignificant correlation was obtained between fasting blood sugar levels and the ratio of neutrophil lymphocytes in the elderly $(\mathrm{p}=0.161 ; \mathrm{r}=0.195)$. An insignificant correlation was found between blood glucose levels after two hours of postprandial with the neutrophil-lymphocyte ratio in the elderly $(\mathrm{p}=0.595 ; \mathrm{r}=0.075)$. HbAlc level and the lymphocyte ratio in the elderly also showed a non-significant correlation $(\mathrm{p}=0.873 ; \mathrm{r}=-0.023)$

Conclusion: There is no significant correlation between blood sugar level and neutrophillymphocyte ratio as a marker of diabetes mellitus in the elderly.
\end{abstract}

Keywords: ratio of neutrophil-lymphocytes, diabetes mellitus, elderly.

1) Student of Faculty of Medicine, Widya Mandala Catholic University of Surabaya, Jl. Kalisari Selatan No.1 Surabaya. Email : dheadasilva@gmail.com

2) Cardiology Department, Faculty of Medicine, Widya Mandala Catholic University of Surabaya, J1. Kalisari Selatan No. 1 Surabaya

3) Neurology Department, Faculty of Medicine, Widya Mandala Catholic University of Surabaya, J1. Kalisari Selatan No. 1 Surabaya 


\section{INTRODUCTION}

Diabetes Mellitus (DM) is a chronic metabolic disease characterized by high blood sugar levels from defects in insulin secretion by the pancreas, insulin action, or both. ${ }^{1}$ Based on the results of the Riset Kesehatan Dasar (Riskesdas) in 2018, DM patient in Indonesia is dominated by the elderly group. According to Law No. 13/1998 concerning Elderly Welfare, the elderly is a person who has aged 60 years and over. The prevalence of DM at Riskesdas in 2918 was dominated by patients age 55-64 years, 6.3\%, followed by ages 65-74 years, which is $6.0 \%$, and age of $\geq 75$ years, which is $3.3 \%{ }^{2}$ This is because there is a functional decrease in organ systems that occurs in the elderly group representing a reduction of peripheral cell tolerance to the effects of insulin (insulin resistance). There are also secondary factors, namely lifestyle and other comorbidities. ${ }^{3}$

International Diabetes Federation (IDF) states that Indonesia is a country with the 7th most DM sufferers in the world, amounting to 8.5 million sufferers. ${ }^{4}$ The incidence of DM, according to Riskesdas in 2018, shows that there was an increase from $1.5 \%$ in 2013 to $2.0 \%$ in 2018 in the population aged $\geq 15$ years. DM sufferers in the Province of East Nusa Tenggara (NTT) rank lastly at $0.9 \%{ }^{2}$ It is also known that the proportion of routine blood sugar levels checked in the population aged $\geq 15$ years in NTT ranks lowest at $0.5 \%{ }^{2}$ This finding is assumed because the community has not done routine blood sugar level checks, so the prevalence of DM in NTT seems to be classified as low. One of the causes of the problem is limited resources, namely the limited number of health workers carrying out routine checks and inadequate laboratory facilities, as well as the distance to the health service. Based on data from the Sikka District Health Office, the number of elderly who suffer from DM in 2018 is 236 people out of 31,164 older people or around $0.008 \%$, both those who live with their families or who live in Panti Jompo.

Although the recorded incidence of DM in NTT is low, the number of DM complications in the elderly, namely hypertension, cerebrovascular accident (CVA), and coronary heart disease (CHD), is quite high as many as 1,274 people, 241 people, and 35 people respectively. The diagnosis of DM requires an expensive examination and is not available in all laboratories, especially in primary care facilities. Some studies suggested that the Neutrophil Lymphocyte Ration (RNL) can be used as an alternative marker for DM diagnosis. ${ }^{5,6}$ 
RNL, in recent years, has become a potential new marker for chronic inflammation. In chronic inflammation, the neutrophil count will increase, and the lymphocyte count will decrease. ${ }^{6}$ RNL examination can be done in all level 1 health facilities and clinics that have simple laboratory facilities. It is hoped that this examination can be an alternative for the initial screening of patients with diabetes, especially in the elderly.

Based on the above background, the researcher is interested in researching one of the Panti Jompo in the City of Maumere, NTT, specifically the Panti Jompo Padu Wau. Screening of diabetes mellitus in this Panti Jompo had never been done using standard parameters such as blood sugar or HbAlc. By doing this research, it is hoped that it can increase contributions to the health data of the elderly in Indonesia, particularly inMaumere, NTT.

\section{METHOD}

This research was an observational analytic study with a cross-sectional approach.

In this research, the population used was all the elderly who live in the Panti Jompo Padu Wau Maumere.

The sample in this research was all the elderly in Panti Jompo Padu Wau, who met the inclusion and exclusion criteria within the research period, which began in July, for two days, 21 and 22 July 2019.

The sampling technique in this research used a consecutive sampling method. All subjects who came and met the inclusion and exclusion sampling criteria were included in the research until the required sample size was met. The inclusion criteria for this research were the elderly who are in Panti Jompo Padu Wau, aged 60-80 years, and willing to be the subject of research by signing informed consent. The exclusion criteria were elderly with fever, known through axillary temperature measurements $>37.5^{\circ} \mathrm{C}$, elderly who consume antibiotics, and consume corticosteroids, and elderly with ulcers. In this research, some samples weredropped due to incomplete data.

This study's procedure was that measured respondents' blood sugar levels (with fasting prerequisites), postprandial blood sugar for two hours, HbA1c, and complete blood tests.

\section{RESULTS}

The study results based on the essential characteristics of the study subjects consisted of gender, marital status, age, blood pressure, waist circumference, and body weight. Based on gender, female respondents dominated the research, with 32 people $(60.4 \%)$. In the measurement of blood pressure, systolic and diastolic 
pressure of the elderly were still within normal limits, namely $139.3 \pm 22.69$ $\mathrm{mmHg}$ and $80.2 \pm 14.20 \mathrm{mmHg}$. According to waist circumference, the mean waist circumference was still within the normal range, which is $84.7 \pm 11.29$ $\mathrm{cm}$. Based on body weight, an average of $45.7 \pm 9.42 \mathrm{~kg}$ was obtained.

From the examination of capillary and venous blood sugar profiles, the subjects' average fasting blood sugar were $98.2 \mathrm{mg} / \mathrm{dL}$. Meanwhile, the examination of two-hours postprandial blood sugar levels showed an average of $136.5 \mathrm{mg} / \mathrm{dL}$. the results of the HbAlc examination showed an average of 5.4\%.

On a complete blood examination, the respondents showed that the mean (average) WBC level was 8542.1 x $106 /$ $\mathrm{L}$, and the mean $\mathrm{Hb}$ level was $12.6 \mathrm{~g} / \mathrm{dL}$. Also, Neutrophil levels were found to be $61.6 \%$, while Lymphocyte levels were found to be $30.6 \%$. Based on the Hb group, it was found that respondents with the $\mathrm{Hb}$ group $\geq 11 \mathrm{~g} / \mathrm{dL}$ were higher, which was $43(81 \%)$ compared to the $\mathrm{Hb}$ group $<11 \mathrm{~g} /$ $\mathrm{dL}$, which is ten people (19\%).

Characteristics of respondents based on the HbAlc group were known that the mean neutrophil levels in respondents with the $\mathrm{HbA} 1 \mathrm{c}$ group $\geq 6.5 \%$ were higher than the HbA1c group $<6.5 \%$, which was 69.2 $\pm 8.69 \%$. While the mean lymphocyte levels in respondents with the HbAlc group $\geq 6.5 \%$ were lower than the HbA1c group $<6.5 \%$, which is $21.0 \pm 4.17 \%$. Also, the mean neutrophil-lymphocyte ratio in respondents with the HbA1c group $\geq 6.5 \%$ was higher than the HbAlc group $<6.5 \%$, which was $3.3 \pm 0.94 \%$.

Respondents on fasting blood sugar (GDP) group test yielded mean neutrophil levels $\geq 126 \mathrm{mg} / \mathrm{dL}$ higher than the GDP group $<126 \mathrm{mg} / \mathrm{dL}$, which was $65.8 \pm$ $10.60 \%$. While the mean lymphocyte level in respondents with a GDP group $\geq 126$ $\mathrm{mg} / \mathrm{dL}$ is lower than the GDP group < $126 \mathrm{mg} / \mathrm{dL}$ which is $26.3 \pm 3.60 \%$. In addition, the mean neutrophil lymphocyte ratio in respondents with a GDP group $\geq$ $126 \mathrm{mg} / \mathrm{dL}$ is lower than the GDP group $<126 \mathrm{mg} / \mathrm{dL}$ which is $2.5 \pm 0.75 \%$.

In the blood group 2 hours postprandial (GD2jPP), the mean neutrophil level was found in respondents with the GD2jPP group $\geq 200 \mathrm{mg} / \mathrm{dL}$ higher than the GD2jPP group $<200 \mathrm{mg} /$ dL which was $68.9 \pm 6.30 \%$. While the mean lymphocyte levels in respondents with the GD2jPP group $\geq 200 \mathrm{mg} / \mathrm{dL}$ were lower than the GD2jPP group $<200$ $\mathrm{mg} / \mathrm{dL}$, which was $25.3 \pm 2.20 \%$. The mean level of neutrophil-lymphocyte ratio in respondents with the GD2jPP group $\geq$ $200 \mathrm{mg} / \mathrm{dL}$ was higher than the GD2jPP group $<200 \mathrm{mg} / \mathrm{dL}$, which was $2.7 \pm$ $0.50 \%$. 
Correlation analysis of blood sugar levels with lymphocyte neutrophil ratio as a marker of diabetes mellitus in the elderly using the Spearman Correlation test showed that between fasting blood sugar levels with neutrophil-lymphocyte ratios in the elderly, there was a non-significant, very weak positive correlation $(p=0.161$; $r=0.195)$. between the blood sugar levels 2 hours postprandial with ratio of neutrophil lymphocytes in the elderly, there was non-significant, very weak positive correlation $(\mathrm{p}=0.595 ; \mathrm{r}=0.075)$. Whereas between HbAlc levels with lymphocyte ratios in the elderly, there was non-significant, very weak negative correlation $(\mathrm{p}=0.873 ; \mathrm{r}=-0.023)$.

\section{DISCUSSION}

Several studies have shown that the ratio of neutrophil lymphocytes will increase in people with DM who have chronic inflammation. ${ }^{5,6}$ In contrast the results of this study, found insignificant correlation between the ratio of neutrophil lymphocytes with blood sugar levels as a marker of diabetes mellitus in the elderly. A study conducted by Shiny A. et al. in 2013 showed an association between an increase in leukocyte count and the incidence of type 2 diabetes in elderly. ${ }^{6}$ According to said study, epidemiological reports showed that the prevalence of DM increases with age, settling before it finally declines. From WHO data it is found that after 30 years, blood sugar levels will rise 1-2 mg/year during fasting and will rise by 5.6-13 $\mathrm{mg} \%$ / year at 2 hours postprandial. ${ }^{5,7}$

Research conducted at Panti Jompo Padu Wau Maumere showed insignificant results, which was thought to be related to the examination of $\mathrm{HbAlc}$ levels. Examination of $\mathrm{HbAlc}$ levels is the standard gold examination for the diagnosis of DM, which can be affected by conditions such as those found in this study, relating to high incidence of anemia and history of malaria that were not examined. ${ }^{8,9}$ other factors, such as genetic variation of each different respondent, are difficult to eliminate. Therefore, the suggestion for further research is to conduct an $\mathrm{HbAlc}$ examination in patients who are not anemic or have a history of malaria $^{10,11,12}$.

\section{CONCLUSION}

Based on the results, it can be concluded that there was no significant correlation between fasting blood sugar levels with neutrophil-lymphocyte ratio in the elderly. There was also no significant correlation between blood sugar levels in the two-hours postprandial with the ratio of neutrophil-lymphocytes in the elderly, and there was an insignificant correlation between the levels of Hbalc with the ratio 
of neutrophil-lymphocytes in the elderly in

Panti Jompo Padu Wau Maumere. These results have not been able to support alternative marker for the diagnosis of diabetes mellitus.

\section{REFERENCES}

1. ADA - American Diabetes Association. Diagnosis of diabetes and prediabetes. Diabetes Care. 2012;35(1):11-63.

2. Riskesdas. Hasil Utama Riskesdas 2018 Kesehatan, Kementerian. 2018;

3. Rochmah W. Diabetes Meliitus Usia Lanjut. Manaj Kedokt Indones. 2007;

4. IDF IDF. Diabetes Atlas Seventh Edition. Vol. 7, International Diabetes Federation. 2015. 17-144 p.

5. Shiny A, Bibin YS, Shanthirani CS, Regin BS, Anjana RM, Balasubramanyam $\mathrm{M}$, et al. Association of NeutrophilLymphocyte Ratio with Glucose Intolerance: An Indicator of Systemic Inflammation in Patients with Type 2 Diabetes. Diabetes Technol Ther [Internet]. 2014;16(8):524-30.

6. Lou M, Luo P, Tang R, Peng Y, Yu $\mathrm{S}$, Huang $\mathrm{W}$, et al. Relationship between neutrophil-lymphocyte ratio and insulin resistance in newly diagnosed type 2 diabetes mellitus patients. BMC Endocr Disord. 2015;15(1).

7. Sudigdo S dan SI. Dasar-Dasar Metodologi Klinis Edisi Ke-4. In: Dasar-Dasar Metodologi Klinis Edisi Ke-4. 2011.

8. World Health Organization. Use of glycated haemoglobin (HbA1c) in the diagnosis of diabetes mellitus: abbreviated report of a WHO consultation. Diabetes Res Clin Pract [Internet]. 2011;93(3):299309.

9. Perkeni. Penatalaksanaan DM Sesuai Konsensus Perkeni 2015. Perkeni. 2015;1-7.

10. Perkins BA, Ficociello LH, Roshan B, Warram JH, Krolewski AS. In patients with type 1 diabetes and new-onset microalbuminuria the development of advanced chronic kidney disease may not require progression to proteinuria. Kidney Int. 2010;77:57-64.

11. Parving HH, Andersen AR, Smidt UM, Svendsen PA. Early aggressive antihypertensive treatment reduces rate of decline in kidney function in diabeticnephropathy. Lancet. 1983;1 :1175-9.

12. Rudiger A, Burckhardt OA, Harpes P, Müller SA, Follath F. The relative lymphocyte count on hospital admission is a risk factor for long-term mortality in patients with acute heart failure. Am J Emerg Med. 2006;24:451-4. 